\title{
TERJEMAH DWIBAHASA Pengantar ke Arah Pendekatan Linguistik
}

\author{
Nurlaila \\ Program Studi Pendidikan Bahasa Arab Sekolah Tinggi Agama Islam Negeri Batusangkar \\ Korespondensi: Jl. Sawah tabing No. 10 Rambatan Batusangkar \\ e-mail: nur.laila304@gmail.com
}

\begin{abstract}
Translation is a process of translating messages from the source language to the target one by preserving the intended meaning of the original sources. This can be achieved by following three main stages: analyzing the message of the source language, translating and reconstructing message by reexpressing in target language so that the translated version is acceptable and readable in terms of form and style of the target language. Since source and target languages have their own type and grammatical rules, a good translations, therefore, should use natural forms of target language and communicate as much as possible the meaning intended by the source language into target language while preserving the 'dynamics' source language texts.
\end{abstract}

Kata kunci: terjemah, linguistik, bahasa sumber, bahasa sasaran

\section{PENDAHULUAN}

$\mathrm{K}$ egiatan terjemah sudah berumur cukup tua, sama dengan manusia mengenal lambang-lambang bahasa lisan. Pada awalnya, jika seseorang mengetahui dua bahasa, dia dianggap boleh menjadi penerjemah tanpa memerlukan pengetahuan lanjut, pendapat ini kini dianggap tidak relevan. Pakarpakar dalam bidang penerjemahan telah menghasilkan teori dan prinsip yang menjadi pedoman dalam penerjemahan.

Dari segi peranannya, terjemahan dapat berfungsi sebagai jembatan yang menghubungkan antar bangsa yang berbeda bahasanya, karena melalui karyakarya terjemahan yang monumental dapat dipelajari kemajuan ilmu pengetahuan dan teknologi yang dicapai oleh bangsa lain. Disamping itu melalui upaya penerjemahan ini karya-karya para ahli di seluruh dunia akan lebih terpublikasi dan terbaca secara maksimal.

Kegiatan penerjemahan sekarang ini tidak hanya dibutuhkan dalam dunia pendidikan, keagamaan atau sosio-kultural, tapi juga dalam dunia usaha seperti dalam promosi dan pemasaran produk. Oleh karena itu dibutuhkan tenaga penerjemah yang terampil dan berdedikasi tinggi. Dalam tulisan ini akan dibahas bagaimana konsep terjemah, klasifikasi dan prosesnya, bagaimana prinsip-prinsip yang terkait dengan bahasa sumber dan bahasa sasaran serta bagaimana interferensi yang terjadi dalam proses terjemah.

\section{KONSEP TERJEMAH}

J.C. Catford (1978:22) mendefinisikan terjemahan sebagai pengalihan wacana dalam bahasa sumber dengan wacana padanannya dalam bahasa sa- 
saran. Nida dan Charles R. Taber (1969: 24) menjelaskan bahwa menerjemahkan merupakan kegiatan menghasilkan kembali dalam bahasa sasaran, bentuk yang sewajarnya sesuai dengan pesan dalam bahasa sumber, yang pertama term makna dan yang kedua term gaya bahasanya. Karena kegiatan terjemahan tidak hanya menerjemahkan makna bahasa sumber ke dalam bahasa sasaran tetapi juga menerjemahkan gaya bahasa yang digunakan dalam bahasa sumber ke dalam bahasa sasaran sesuai dengan aturanaturan kebahasaan yang berlaku dalam bahasa sasaran tersebut. Sementara Yusuf (1994: 8) mengartikan terjemah sebagai suatu proses pengalihan pesan yang terdapat di dalam teks bahasa pertama atau bahasa sumber (source language) dengan padanannya di dalam bahasa kedua atau bahasa sasaran (target language).

Larson (1984: 3) mengemukakan bahwa menerjemahkan pada dasarnya adalah mengubah suatu bentuk menjadi bentuk lain. Simatupang (2000: 1) menjelaskan bahwa bentuk lain yang dimaksud bisa berupa bentuk bahasa sumber atau bahasa sasaran, karena terjemahan bisa dilakukan dalam bahasa yang sama (intralingual) atau dari satu bahasa ke bahasa lain (interlingual). Jika kata bapak dalam bahasa Indonesia diterjemahkan ke dalam bahasa Indonesia, maka bentuk yang dapat dipakai untuk menerjemahkannya adalah ayah. Terjemahan seperti ini disebut terjemahan intralingual. Jika kata bapak diterjemahkan ke dalam bahasa Inggris, maka terjemahannya adalah father. Terjemahan seperti ini disebut terjemahan interlingual. Dalam hal ini bahasa Indonesia disebut bahasa sumber (source language) dan bahasa Inggris disebut bahasa sasaran atau penerima (target atau receptor language).

Dari contoh di atas, terlihat bahwa yang dialihkan dari bahasa sumber ke bahasa sasaran bukanlah bentuk bahasa sumbernya, melainkan makna bentuk bahasa sumbernya. Jadi, bukan kata bapak yang terdiri dari urutan fonem $/ \mathrm{b} /$, /a/, /p/, /a/, dan $/ \mathrm{k} /$ ) yang dialihkan, tetapi makna bentuk tersebut. Setelah makna dialihkan ke dalam bahasa sasaran, maka dicarilah bentuk yang wajar dalam bahasa sasaran yang mengandung makna bapak. Demikian juga jika bentuk kata mustasyfâ dalam bahasa Arab diterjemahkan ke dalam bahasa Indonesia, maka maknanya dialihkan ke dalam bahasa Indonesia sehingga terjemahannya (bentuk bahasa Indonesianya) menjadi frasa rumah sakit.

\section{KLASIFIKASI TERJEMAH}

Larson (1984: 4) membagi terjemahan menjadi meaning-based translation (terjemahan berdasarkan makna) dan form-based translation (terjemahan berdasarkan bentuk). Simatupang (2000: 39) mambagi terjemahan menjadi dua macam, yaitu terjemahan harfiah (literal translation) dan terjemahan bebas (nonliteral translation). Sementara Nida (1969: 202) juga mengemukakan dua jenis terjemahan, yaitu: (1) terjemahan dinamis, yaitu terjemahan yang mementingkan makna daripada bentuk, yang bertujuan untuk menghasilkan padanan dinamis di dalam bahasa sasaran yang merupakan hakikat terjemahan, karena padanan dinamis inilah yang mengalihkan pesan yang terdapat dalam teks asli. (2) terjemahan yang berdasarkan bentuk, yaitu terjemahan yang mengandung fitur-fitur bentuk teks bahasa sumber. Sedangkan Newmark (1988: 4547) menggunakan delapan terminologi dalam klasifikasinya. Kedelapan terminologi tersebut ialah word-for-word, literal, faithful, semantic, communicative, idiomatic, free, dan adaptation yang tersusun ke dalam dua lingkup, yaitu empat metode pertama yang dekat ke bahasa sumber dan empat metode kedua yang dekat ke bahasa target. 
Dalam hal ini, terjemahan harfiah dapat disamakan dengan terjemahan bentuk sedangkan terjemahan bebas dapat disamakan dengan terjemahan makna dan terjemahan dinamis, karena pada dasarnya terjemahan harfiah adalah terjemahan yang berdasarkan bentuk, sebaliknya terjemahan bebas adalah terjemahan yang lebih mementingkan makna daripada sekedar bentuk bahasa sumber, sehingga yang diterjemahkan adalah makna dari bentuk bahasa sumber guna menghasilkan padanan yang dinamis dan sedekat-dekatnya dalam bahasa sasaran dan dalam pengungkapannya kembali harus mentaati aturanaturan yang berlaku dalam bahasa sasaran.

Terjemahan secara harfiah tidak mengungkapkan makna bahasa sumber di dalam bahasa sasaran yang dialihkan ke dalam bahasa sasaran adalah bentuk bahasa sumber, bukan makna yang terkandung dalam bahasa sumber. Untuk memperoleh terjemahan yang baik dan wajar, terjemahan harus mengungkapkan kembali makna yang telah dialihkan dari bahasa sumber ke bahasa sasaran itu dengan mengikuti aturan-aturan yang berlaku dalam bahasa sasaran (Simatupang, 2000; 40). Meskipun demikian, bukan berarti terjemahan harfiah tidak bisa dipakai sama sekali, karena terjemahan harfiah merupakan langkah pertama penerjemahan. Bila terjemahan harfiah tersebut mampu menyampaikan makna bahasa sumber, maka kegiatan penerjemahan berhenti sampai disitu. Namun jika belum, maka kegiatan penerjemahan mesti harus dilanjutkan dengan terjemahan makna. Dengan demikian, dari sebuah hasil karya terjemahan yang utuh, beberapa bagiannya mungkin berupa terjemahan harfiah. Disamping itu, masih terdapat jenis-jenis terjemahan lain, namun secara garis besar tetap dapat dikelompokkan pada dua golongan ini, yaitu terjemahan harfiah dan terjemahan makna.

\section{PROSES TERJEMAH}

Nida dan Taber (1969: 33) membagi proses penerjemahan ke dalam tiga tahapan, yaitu (1) analisis pesan pada bahasa sumber (2) transfer dan (3) rekonstruksi pesan yang ditransfer ke dalam bahasa target. Tahap analisis adalah proses di mana hubungan gramatikal dan makna atau kombinasi kata dianalisis. Pada tahap transfer, bahan yang telah dianalisa dalam tahap pertama ditransfer dalam pikiran penerjemah dari bahasa sumber ke dalam bahasa target. Tahap rekonstruksi adalah tahap di mana penulis menuliskannya kembali atau mengekspresikan kembali bahan sedemikian rupa sehingga produk terjemahan dapat diterima dan dibaca dalam aturan dan gaya bahasa target.

Sementara Bell (1991: 60) menggambarkan proses terjemahan sebagai proses interaktif yang berisi tiga tahap utama, yaitu sintaksis, semantik, dan pengolahan pragmatik. Masing-masing harus dilibatkan baik dalam analisis maupun sintesis. Bell menjelaskan bahwa proses penerjemahan tidak linear di mana satu tahap diikuti tahap berikutnya dalam rangkaian terbatas. Proses penerjemahan merupakan proses yang terpadu, walaupun setiap tahapan harus dilalui, namun urutannya tidak tetap. Pelacakan kembali, revisi, dan pembatalan atas keputusan sebelumnya merupakan norma, bukan sekedar pengecualian.

Ronald H. Bathgate (dalam Widyamartaya, 2003: 15-18) dengan lebih terperinci mengemukakan tujuh langkah dalam proses penerjemahan, yaitu:

\section{Tuning (penjajakan)}

Bila ingin menerjemahkan, maka terlebih dahulu harus dilakukan "tuning", yaitu menjajaki bahan yang akan diterjemahkan. Sebab bahasa terjemahan harus selaras dengan bahasa yang diterjemahkan dalam hal makna dan gayanya, maka terlebih dahulu harus 
diketahui bahan yang hendak diterjemahkan itu bahasa siapa: bahasa seorang pujanggakah, ahli hukumkah dan sebagainya. Ragam bahasa terjemahan yang tepat harus sudah dapat kita tentukan sejak permulaan. Sebuah sajak harus menjadi sebuah sajak, bukan sebuah prosa. Sejak semula seorang penerjemah harus dapat menentukan sikap atau pendekatan mental yang tepat, harus dapat membayangkan pilihan kata atau susunan frase dan kalimat yang selaras. Isi bahan yang akan diterjemahkan mungkin belum seluruhnya dipahami pada taraf permulaan tapi nada harus sudah selaras sejak permulaan dipikiran dan hati penerjemah.

\section{Analysis (penguraian)}

Setiap kalimat dalam bahasa sumber harus diurai kedalam satuan-satuan berupa kata-kata atau frase-frase. Kemudian penerjemah harus dapat menentukan hubungan sintaksis antara berbagai unsur kalimat itu. Pada tahap ini, perlu juga penerjemah sudah dapat melihat hubungan antara unsur-unsur dalam bagian teks yang lebih besar agar penerjemah mulai dapat berpikir untuk menciptakan konsistensi dalam terjemahannya. Analisis ini masih perlu berlanjut dalam tahap pemahaman dan peristilahan. Bila istilah-istilah yang dipakai konsisten maka terjemahan lebih mudah dipahami.

\section{Understanding (pemahaman)}

Sesudah penerjemah melihat satuan-satuan dalam setiap kalimat dan unsur-unsur dalam bagian teks yang lebih besar, maka penerjemah berusaha memahami isi bahan yang akan diterjemahkan. Penerjemah harus menangkap gagasan utama tiap paragraf dan ide-ide pendukung dan pengembangnya. Penerjemah harus menangkap hubungan gagasan satu sama lain dalam tiap paragraf dan antar paragraf.

\section{Terminology (peristilahan)}

Setelah pemahaman isi dan bentuk dalam bahasa sumber, penerjemah kemudian berpikir tentang pengungkapannya dalam bahasa sasaran (bahasa terjemahan). Terutama mencari istilahistilah, ungkapan-ungkapan dalam bahasa sasaran yang tepat, cermat dan selaras. Kata, ungkapan atau istilah yang dipakai dalam bahasa sasaran jangan sampai menyesatkan.

\section{Restructuring (perakitan)}

Setelah masalah bahasa sasaran diatasi dan semua kata, istilah dan ungkapan yang diperlukan untuk menyusun terjemahan dalam bahasa sasaran tersedia, maka penerjemah tinggal menyusun bahan-bahan tersebut menjadi terjemahan yang selaras dengan normanorma dalam bahasa sasaran. Bentuk terjemahan itu selain harus selaras dengan pemakai bahasa sasaran, juga harus menerjemahkan secara tepat makna dan gaya bahasa sumber.

\section{Checking}

Sebagaimana sebuah tulisan yang baik kerapkali merupakan hasil revisi berkali-kali, demikian juga sebuah hasil terjemahan. Draft pertama harus diperiksa kesalahan-kesalahannya dalam penulisan kata dan diperbaiki susunansusunan kalimatnya untuk menghasilkan kalimat yang lebih efektif.

\section{Discussion}

Cara terbaik untuk mengakhiri proses penerjemahan adalah penerjemah mendiskusikan hasil terjemahannya, baik menyangkut isi maupun bahasanya.

Dari tujuh langkah penerjemahan di atas, dapat diringkas menjadi tiga langkah penerjemahan, yaitu: (1) analisis teks sumber guna memahami pesan yang terkandung, (2) pengalihbahasaan dalam pikiran penerjemah, dan (3) pengalihan dan penyerasian dalam bahasa sasaran. Dalam langkah (2) biasanya penerjemah 
melakukan dulu apa yang disebut diverbalisasi (melepaskan diri dari ikatan kata dan kalimat), setelah itu ia dapat melakukan cloze translation yaitu upaya melakukan terjemahan kalimat demi kalimat, bahkan jika ada kesulitan, dapat dimulai dengan melakukan penerjemahan kata demi kata atau harfiah yang sangat berguna untuk memahami baik makna kata maupun hubungan gramatikalnya atau konstruksi teksnya. Langkah-langkah tersebut sebaiknya diikuti oleh seorang penerjemah, meskipun tidak harus secara ketat, agar hasil terjemahan menjadi lebih baik.

\section{BAHASA SUMBER DAN BAHASA SASARAN}

Penerjemahan adalah upaya untuk mengalihkan pesan yang terkandung dalam teks suatu bahasa (bahasa sumber) kedalam teks bahasa lain (bahasa sasaran). Oleh karena itu, dari seorang penerjemah dituntut penguasaan bahasa sumber dan bahasa sasaran. Disamping itu, penerjemah yang baik juga memiliki kesiapan untuk memahami latar belakang budaya bahasa sumber dan bahasa sasaran. Jadi, kemampuan berbahasa asing atau bahasa ibu (bahasa pertama) saja tidak cukup. Ia harus mampu menempatkan dirinya dalam kedua bahasa itu secara bergantian, bahkan ia harus mampu menguasai latar belakang budaya dari setiap bahasa yang terlibat dalam penerjemahan yang dilakukannya.

Bahasa sumber dan bahasa target masing-masing memiliki tipe dan aturan gramatika yang berbeda. Sakri (1985: 9) mengemukakan bahwa setiap bahasa mempunyai adatnya sendiri-sendiri dan itulah salah satu hal yang menyebabkan pekerjaan menerjemahkan tidak semudah yang diperkirakan. Menerjemahkan suatu bahasa ke bahasa lain bukanlah memadankan kata asal dengan kata penerimanya karena menerjemahkan tidak harus sama dengan bahasa aslinya.
Untuk memperoleh terjemahan yang terbaik, Larson (1984: 6) mengemukakan tiga syarat, bahwa terjemahan harus (1) memakai bentuk-bentuk bahasa sasaran yang wajar, (2) mengkomunikasikan sebanyak mungkin makna bahasa sumber tersebut kedalam bahasa sasaran, dan (3) mempertahankan dinamika teks bahasa sumber, yaitu kesan yang diperoleh atau respon yang diberikan oleh penutur bahasa sumber ketika membaca teks asli harus sama dengan kesan dan respon penutur bahasa sasaran ketika membaca teks terjemahan. Tuntutan untuk memenuhi ketiga persyaratan di atas sangat sulit bagi seorang penerjemah, seperti dapat ditemukan dalam berbagai hasil karya terjemahan.

Syarat-syarat yang dikemukakan oleh Larson di atas menjelaskan bahwa dalam mengungkapkan makna yang dialihkan dari bahasa sumber ke dalam bahasa sasaran, bentuk-bentuk bahasa sasaran yang digunakan untuk mewujudkannya haruslah sewajar mungkin menurut aturan-aturan yang berlaku dalam bahasa sasaran. Disamping kewajaran menurut bahasa sasaran seperti ini semaksimal mungkin diusahakan, harus juga diperhatikan agar makna yang dialihkan itu tetap sama, tidak lebih dan tidak kurang.

Untuk memperoleh terjemahan terbaik seperti dikemukakan Larson di atas, maka penerjemah harus menguasai bahasa sumber dan bahasa sasaran. Seorang yang hanya fasih berbahasa Inggris belum tentu mampu menerjemahkan kedalam bahasa Indonesia jika ia tidak menguasai bahasa Indonesia dengan baik. Ia juga harus menguasai berbagai faktor yang mempengaruhi pemahaman atas teks sumber dan terjemahannya (teks sasaran). Dalam hal ini terdapat beberapa hal yang harus diperhatikan oleh penerjemah, yaitu: 
1. Mencari padanan yang tepat dalam terjemahan

Kata, frasa dan kalimat, yang semuanya bisa disebut bentuk, mempunyai potensi untuk mengandung beberapa makna, tergantung lingkungan dan konteksnya. Oleh karena itu, seorang penerjemah harus selalu dapat melihat konteks kata agar dia dapat mengartikannya dengan tepat dan mencari padanannya dalam bahasa sasaran (Simatupang, 2000: 44).

a. Padanan leksikal yang non-harfiah (makna sekunder) dan makna kiasan

Banyak contoh menunjukkan bahwa padanan kata dalam bahasa sumber tidaklah selalu merupakan padanan harfiah dalam bahasa sasaran, atau yang disebut padanan leksikal yang non harfiah (non-literal equivalents) (Simatupang, 2000: 45). Berikut terdapat beberapa contoh kata يد dalam Al-Qur'an dalam berbagai konteks dengan arti yang berbeda:

$$
\begin{aligned}
& \text { (1) فاغسلوا وجوهكم و أيديكم إلى المرافق (المائدة: جال) }
\end{aligned}
$$

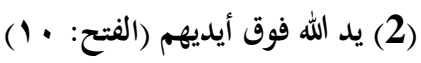

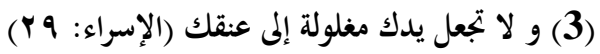

$$
\begin{aligned}
& \text { (4) مصدقا لما بين يديه (البقرة: 9V) }
\end{aligned}
$$

Pada contoh-contoh di atas terlihat bahwa hanya kata يد dalam contoh (1) yang mengandung makna harfiah (makna primer), yaitu tangan. Kata \s pada kalimat yang lainnya mengandung makna non-harfiah (makna sekunder) yang muncul karena kata tersebut dipakai bersamasama dengan kata lain dalam konteks yang berbeda-beda.

Dengan demikian dapat diketahui bahwa unsur leksikal disamping mempunyai makna primer juga memiliki makna sekunder. Makna primer ialah makna yang muncul di dalam pikiran kita jika kita mendengar kata tersebut diucapkan secara terpisah, tidak dalam konteks. Sedangkan makna sekunder ialah makna yang diperoleh kata jika dipakai dengan kata lain, atau jika berada dalam suatu konteks dengan kata lain (Simatupang, 2000: 45-46). Makna yang dipahami ketika kata يد diucapkan secara terpisah adalah makna primer, sedangkan makna yang dipahami ketika kata tersebut berada berdampingan dengan kata lain adalah makna sekunder. Selain makna primer dan sekunder di atas, kata juga mengandung makna kiasan (atau makna figuratif) seperti metonimi, sinekdoki, idiom dan eufemisme.

b. Pilihan kata berdasarkan konteks situasional

Dalam terjemahan juga perlu diperhatikan bahwa pilihan kata yang digunakan dalam berbahasa berdasarkan pada konteks situasional. Pilihan kata yang digunakan setidaknya tergantung pada tiga hal, yaitu siapa yang berbicara, kepada siapa pembicaraan ditujukan, dan mengenai apa atau siapa pembicaraan tersebut (Simatupang, 2000: 52). Komponenkomponen situasional inilah yang akan mempengaruhi pemilihan padanan yang paling tepat dalam penerjemahan, sehingga dapat menghasilkan terjemahan yang wajar sesuai dengan konteksnya dalam bahasa sumber.

\section{c. Kolokasi}

Selain faktor-faktor penentu pilihan kata seperti dikemukakan di atas, terdapat pula syarat-syarat lain, yaitu aturan kolokasi. Kolokasi merupakan aturan yang membolehkan suatu kata bergabung dengan kata yang lain untuk membentuk konstruksi yang lebih besar dan dapat berterima secara gramatikal dan semantik (Simatupang, 2000: 55). Makan uang atau makan keringat 
adalah contoh kata-kata yang berkolokasi untuk membentuk konstruksi yang lebih besar.

Kolokasi berbeda dari idiom, karena kolokasi merupakan kombinasi tetap beberapa kata dan makna masing-masing kata pembentuknya pada dasarnya dipertahankan. Sedangkan idiom adalah frasa yang unsur-unsur pembentuknya tetap (fixed) dan maknanya bukan penjumlahan makna unsur-unsur pembentuknya, tetapi menghasilkan makna baru, sehingga idiom diperlakukan sebagai sebuah kosakata. Hidung belang adalah contoh idiom dalam bahasa Indonesia, yang maknanya bukanlah sejenis hidung seperti hidung mancung, melainkan laki-laki yang gila perempuan.

\section{Pergeseran dalam terjemahan}

Perbedaan aturan dan bentuk untuk mengungkapkan makna antara berbagai bahasa akan mengakibatkan pergeseran yang terjadi dalam terjemahan. Pergeseran tersebut mencakup beberapa hal, yaitu (lihat: Simatupang, 2000: 74-82):

\section{a. Pergeseran pada tataran morfem}

Pergeseran yang terjadi pada tataran morfem terlihat pada contoh impossible dalam bahasa Inggris yang diterjemahkan kedalam bahasa Indonesia menjadi tidak mungkin. Dari contoh tersebut terlihat bahwa padanan morfem (morfem terikat) im dalam Inggris adalah morfem (morfem bebas) tidak dalam bahasa Indonesia. Begitu juga dalam menyatakan makna jamak pada nomina, dalam bahasa Arab digunakan diantaranya morfem terikat dan , sedangkan dalam bahasa Indonesia digunakan morfem bebas yang mengandung makna jamak seperti beberapa atau dengan perulangan kata.

\section{b. Pergeseran pada tataran sintaksis}

Disamping pergeseran pada tataran morfem, pergeseran juga bisa terjadi pada tataran sintaksis, pergeseran tersebut dapat terjadi dalam beberapa hal, yaitu: (1) pergeseran dari kata ke frasa (2) pergeseran dari frasa ke klausa (3) pergeseran dari frasa ke kalimat (4) pergeseran dari klausa ke kalimat dan (5) pergeseran dari kalimat ke wacana

c. Pergeseran pada kategori kata

Selain pergeseran pada tataran struktur, pergeseran pada kategori kata pun dapat terjadi dalam proses penerjemahan, seperti pergeseran dari nomina ke adjektiva atau dari nomina ke verba. Untuk mencapai kewajaran yang berlaku bagi bahasa sasaran, apa yang dinyatakan dengan kategori nomina dalam bahasa sumber, ketika diterjemahkan kedalam bahasa sasaran bisa menjadi kategori verba atau adjektiva. Seperti kalimat من أين أنت , diterjemahkan dengan kamu datang dari mana?, kata dalam bahasa Arab termasuk kategori nomina, sedangkan kata datang dalam bahasa Indonesia merupakan kategori verba.

\section{d. Pergeseran pada tataran semantik}

Disamping kemungkinan terjadinya pergeseran pada bidang-bidang yang telah disebutkan di atas, pergeseran pun bisa terjadi pada bidang semantik. Pergeseran serupa ini terjadi karena perbedaan sudut pandang dan budaya penutur bahasabahasa yang berbeda. Pergeseran di bidang makna ini mengakibatkan bahwa tidak selalu mungkin memindahkan makna yang terdapat di dalam teks atau bahasa sumber ke dalam teks atau bahasa sasaran secara tepat dan utuh.

Dalam bahasa Inggris dikatakan I think so, maka padanannya dalam 
bahasa Indonesia adalah saya rasa. Orang Inggris berpikir (think) tidak memakai perasaan (feel), sehingga tidaklah wajar dikatakan I feel so untuk mengungkapkan saya rasa begitu. Dengan demikian, berpikir dan merasa dibedakan secara tegas dalam bahasa Inggris.

\section{INTERFERENSI DALAM PENER- JEMAHAN}

Setiap bahasa mempunyai aturanaturan sendiri. Aturan-aturan yang berlaku pada suatu bahasa belum tentu berlaku pada bahasa lain. Hal ini berlaku pada semua unsur bahasa; fonologi, morfologi, sintaksis maupun semantik. Dengan demikian, untuk mengungkapkan makna, setiap bahasa mempunyai caranya sendiri dalam memakai alat-alat bahasa (linguistic devices) (Simatupang, 2000: 74). Oleh karena itu, tingkat kedwibahasaan penerjemah yaitu tingkat penguasaan bahasa sumber dan bahasa sasaran sangat menentukan tingkat interferensi (gejala penggunaan unsurunsur suatu bahasa dalam bahasa lainnya) dalam penerjemahan.

Interferensi dalam penerjemahan dapat terjadi dalam semua unsur bahasa, yaitu tata bunyi (phonic interference), tata kata (lexical interference), tata bahasa (grammatical interference) dan tata makna (semantic interference) (lihat Yusuf, 1994: 71-85). Interferensi tersebut terjadi bila seorang penerjemah (sebagai dwibahasawan) mengidentifikasi sistem fonem, morfem, struktur dan makna bahasa pertama kemudian menggunakannya dalam bahasa kedua. Misalnya frasa good idea (dengan pola Menerangkan dan Diterangkan menurut aturan bahasa Inggris), untuk menghindari interferensi maka dalam menerjemahkannya harus dianalisis terlebih dahulu kata yang menjadi kepala frasa dan kata yang menerangkannya, kemudian disesuaikan kedudukan padanannya dalam aturan bahasa sasaran (bahasa Indonesia), sehingga terjemahannya bukan bagusnya ide tetapi ide bagus atau ide cemerlang (dengan pola Diterangkan dan Menerangkan menurut aturan bahasa Indonesia). Jadi, bentuk frasa dengan pola M-D dalam bahasa Inggris diterjemahkan menjadi frase dengan pola D$\mathrm{M}$ dalam bahasa Indonesia.

\section{PENUTUP}

Terjemah atau dalam bahasa Arab tarjamah dan bahasa Inggris translation merupakan kegiatan mengalihbahasakan teks (termasuk huruf atau transliterasinya) dari bahasa yang ditulis atau dikatakan kepada bahasa lain tanpa mengurangi amanatnya, Pengalihan amanat antar budaya dan atau antar bahasa dalam tataran gramatikal dan leksikal diarahkan pada upaya mempertahankan efek dan wujudnya. Meskipun demikian, sulit bagi penerjemah untuk menghindari terjadinya pergeseran dalam terjemahan, seperti pergeseran pada tataran morfem, sintaksis, kategori kata dan semantik, hal ini disebabkan karena adanya perbedaan bentuk dan aturan antara bahasa sumber dan bahasa sasaran. Demikian juga dengan interferensi dalam terjemahan yang dapat terjadi pada semua unsur bahasa, yaitu tata bunyi, tata kata, tata bahasa dan tata makna.

Oleh karena itu, seorang penerjemah harus menguasai seluk-beluk bahasa yang terlibat dalam proses terjemahan dan dapat menggunakannya sesuai dengan kedudukannya sebagai bahasa sumber dan bahasa sasaran. Di samping itu ia juga harus punya kemampuan menggunakan alat kebahasaan meliputi kamus dwibahasa, ekabahasa dan kamus istilah. 


\section{DAFTAR RUJUKAN}

Catford, J.C., A Linguistic Theory of Translation, London: Oxford University Press, 1978

Hartono, Belajar Menerjemahkan Teori dan Praktek, Malang: UMM Press, 2005

Larson, Mildred L, Meaning-Based Translation, London: University Press of America, 1984:

Newmark, Peter, A Textbook of Translation, New York: Prentice Hall International (UK) Ltd., 1988

Nida, and Charles R Taber, The Theory and Practice of Translation, Leiden: E. J. Brill, 1969:

Daftar Indeks Indeks

bahasa, 60, 47, 48, 49, 50, 51, 52, 53, 54

berpikir, 49,53

budaya, 50, 53, 54
Sakri, Adjat, Ihwal Menerjemahkan, Bandung: ITB Bandung Press, 1985

Simatupang, Maurits D. S., Pengantar Teori Terjemahan, Jakarta: Dirjen Pendidikan Tinggi Depdiknas, 2000

Widyamartaya, A, Seni Menerjemahkan, Yogyakarta: Kanisius, 2003

Yusuf, Suhendra, Teori Terjemah, Bandung: Mandar Maju, 1994

kalimat, 49, 50, 51, 53

linguistik, 60

makna, 47, 48, 49, 50, 51, 52, 53, 54

sasaran, 60, 47, 48, 49, 50, 51, 53, 54 